\title{
Creative and sensitive production of care-educational technology for families of children with gastrostomy ${ }^{a}$
}

\author{
Produção sensível e criativa de tecnologia cuidativo-educacional para famílias de crianças com \\ gastrostomia
}

Producción sensible y creativa de tecnología cuidativo-educativa para familias de niños con gastrostomía

Ana Caroline Silva Caldas ${ }^{1}$ (iD Rosilda Silva Dias ${ }^{1}$

Santana de Maria Alves de Sousa ${ }^{1}$ (iD)

Elizabeth Teixeira ${ }^{2,3}$ (iD

1. Universidade Federal do Maranhão.

São Luís, MA, Brasil.

2. Universidade do Estado do Amazonas.

Manaus, AM, Brasil.

3. Centro Universitário Luterano de Manaus.

Manaus, AM. Brasil.
Corresponding Author:

Ana Caroline Silva Caldas.

E-mail: acarolcaldas@gmail.com

Submitted on $07 / 23 / 2018$.

Accepted on $11 / 20 / 2018$.

DOI: 10.1590/2177-9465-EAN-2018-0144

\begin{abstract}
Objective: To describe the production process of a care-educational technology for families of children with gastrostomy based on the models of Hildegard Peplau and Paulo Freire. Method: Descriptive and qualitative research, carried out from October 2016 to February 2017 in three health units and a residential unit in São Luís, MA, Brazil. Thirteen family members participated. Were used from the creative method sensitive to dynamic body knowledge, semi-structured interview and observation. Thematic analysis. Results: From the problem situations that emerged from the corpus, the contents of the technology were constructed and decoding in subtopics. The technology is of the printed type (booklet), titled The child and his gastrostomy: a guide for families and caregivers. Contains 24 pages and nine content topics, with texts and images. Conclusion: Social evidence that favored the production of a technology that is sensitive to reality, which, after being validated, will help families emerged. Implications for practice: The booklet can be used in the teaching and assistance activities of the families.
\end{abstract}

Keywords: Gastrostomy; Family; Child Care; Educational technology.

\section{RESUMO}

Objetivo: Descrever o processo de produção de uma tecnologia cuidativo-educacional para famílias de crianças com gastrostomia a partir dos modelos de Hildegard Peplau e de Paulo Freire. Método: Pesquisa descritiva, qualitativa, realizada entre outubro de 2016 a fevereiro de 2017 em três unidades de saúde e uma unidade domiciliar em São Luís, MA, Brasil. Participaram 13 familiares. Utilizou-se do método criativo sensivel à dinâmica corpo saber, a entrevista semiestruturada e observação. A análise foi temática. Resultados: Das situações-problema que emergiram do corpus, foram construídos os conteúdos da tecnologia, com descodificação em subtemas. Tecnologia do tipo impressa (cartilha), intitulada A criança e sua gastrostomia: um guia para famílias e cuidadores. Contém 24 páginas e nove tópicos de conteúdo, com textos e imagens. Conclusão: Emergiram evidências sociais que favorecem a produção de uma tecnologia sensível à realidade, que após validação, ajudará as famílias. Implicações para a prática: A cartilha poderá ser utilizada nas atividades assistenciais e de ensino.

Palavras-chave: Gastrostomia; Família; Cuidado da criança; Tecnologia educacional.

\section{RESUMEN}

Objetivo: Describir el proceso de producción de una tecnología curativo-educativa para familias con niños gastrostomizados, a partir de los modelos de Hildegard Peplau y Paulo Freire. Método: Estudio descriptiva, cualitativo, realizado entre octubre 2016 y febrero 2017, en tres unidades de salud y una unidad domiciliar en São Luís, MA, Brasil. Participaron 13 familiares. Método creativo-sensible a la dinámica cuerpo saber, entrevista semiestructurada y observación. Análisis temático. Resultados: De las situación-problema emergidas del corpus, se construyeron contenidos de la tecnología, con la descodificación en subtemas. La tecnología es tipo impresa (cartilla), titulada El niño y su gastrostomía: una guía para familias y cuidadores. Contiene 24 páginas y nueve temáticas, con textos e imágenes. Conclusión: Emergieron evidencias sociales que favorecieron el desarrollo de una tecnología sensible a la realidad que, después de comprobada, ayudará a las familias. Implicaciones para la práctica: La cartilla se puede utilizar en las actividades de enseñanza y asistencia de las familias.

Palabras clave: Gastrostomía; Familia; Cuidado del niño; Tecnología educacional 


\section{INTRODUCTION}

The chronic condition in children and adolescents is characterized by impairment of global development and quality of life permanently and/or for more than three months; they need support for the human functions of interaction, communication, expression and needs of technological support to life. They are also characterized by the vulnerability that may associate changes in physical, emotional, developmental and behavioral conditions and that require health care services, additional to the usual ones, and of primary home care. ${ }^{1}$

In the dimensions of sociability specific to childhood, visits to the doctor, prolonged treatments, hospitalization and various restrictions are necessary, such as absence from school, limitations of daily activities. ${ }^{2}$

These children with chronic problems need more support, not only biomedical interventions. They need planned care and attention capable of predicting their needs, ${ }^{3}$ among them those related to nutritional status.

As oral feeding is insufficient to meet nutritional requirements or inability to use the oral route, enteral nutritional support can be achieved by catheter or ostomy; ${ }^{4}$ gastrostomy is commonly used for an extended period of time or definitively ${ }^{5}$ to feed children with neurological disorders incapable of oral use and with insufficient growth, newborns at risk of aspiration and in children with intractable gastroesophageal reflux disease and delayed gastric emptying.,

Although it is a faster procedure in its manufacture, with a shorter hospitalization time, a faster recovery when performed by the endoscopic route ${ }^{8}$ for the parents, the stoma can cause multiple disorders in the family life due to the dependence of care generated from its manufacturing, the need for long-term care and medical devices in the postoperative period and after hospital discharge. ${ }^{9}$

Therefore, the acceptance of gastrostomy confection leads many families to experience conflicting moments characterized by uncertainty, stress and disagreements between parents. Regarding the values attributed to oral feeding, the loss of this important process has repercussions on a common source of family disorders, since the parents consider oral feeding a pleasant activity for the child, of normality, important social process permeated by affection and union and feeding by gastrostomy breaks the pleasure of oral feeding, makes the activity, artificial, interrupting the family normality, represents extreme guilt and paternal failure besides being seen as a signal to the parents of the serious disability that their child faced and a permanent sign of disability visible to all. ${ }^{10}$

Through the complexity of the care of the child with gastrostomy and the management of the technological device, it is necessary for families to acquire information and specific knowledge to deal with this technology essential for the maintenance of the life of their children. ${ }^{11}$
Nursing plays a fundamental role in the care of children dependent on technology and their families, having to prepare them in the hospital environment to offer daily and safe care to their children at home, however the work process remains centered on the biomedical paradigm, values and techniques to the detriment of socio-cultural aspects. ${ }^{12}$

The care-educational technologies (CET) are tools used by the nurse in the path of possibilities to care/educate and educate/care for oneself and the other, based on the principles of human praxis. ${ }^{13}$ Aim to meet social demands and needs that emerge from innumerable contexts, serve to broaden the learning process of nursing students, educate people who are resistant to hidden issues, encourage acceptance of a new living condition, assist family members/caregivers in the process of caring for the elderly, among others. ${ }^{14-17}$

It is essential the educating role of health professionals, especially the nurse, in the empowerment of families in the process of taking care of children dependent on technology. For this, an interdisciplinary team of professionals interested and participatory and properly informed and motivated families are fundamental for the success of the care to the child with gastrostomy.

The production of a technology focused on the needs of these families strengthens the attendance of the demands of care to these people, as it values their aspects of life and creates possibilities of construction and reconstruction of the knowledge taught. Based on these reflections, it was decided to carry out a study to describe the process of production of a care-educational technology to support the care of families of children with gastrostomy, based on Hildegard Peplau's model of interpersonal relations and the conception of autonomy of Paulo Freire.

\section{METHOD}

This is a descriptive study of a qualitative nature. In order to guide the production of technology, the model of interpersonal relations of Peplau ${ }^{18}$ and the conception of Freire's autonomy ${ }^{19}$ were adopted as theoretical references, theoretical models that come together, considering that learning is significant and leads the human being to become and achieve greater personal development as he/she learns by employing his/hers abilities to express himself/herself fully and freely. It is argued that the interaction between people when permeated by critical and dialogic reflection enables the development of a collective and participatory action. The therapeutic and educational relationship between nurse and patient in an interpersonal process helps to obtain self-determination, adaptation directed at self-competence and independence.

The study was based on the assumptions of the Creative and Sensitive Method (CSM). The method allows exploring the participants' sensitive potential on a topic in this investigation, the experience of families with children gastrostomized, from 
the moment of indication to the preparation of gastrostomy, midterm and late postoperative. The CSM has its foundations based on the group process, participant observation and dynamics of creativity and sensitivity/artistic production. ${ }^{20}$

The study followed the norms for research activities and interventions with humans, in compliance with Resolution $466 / 12$ of the National Health Council, with the inclusion of study participants after formal authorization through the signing of the Informed Consent Form, obtaining approval from the Research Ethics Committee of the Universidade Federal do Maranhão (UFMA), CAAE: 5795491160.0000 .5087$.

The research was developed initially with the recruitment of the participants in the health units. Among the three health units selected, two correspond to hospitals, one state and the other federal, and the third health unit is a charitable and educational philanthropic entity that promotes integral care for the disabled person. The search for families in the late postoperative period, at home, also occurred in the units mentioned previously. These scenarios were chosen because these sites perform the indication, making of the gastrostomy and monitoring of the children with gastrostomies.

Participants were 10 families who were living the process of making gastrostomy of children under 12 years of age in the hospital, outpatient clinic and domicile. Among the ten participating families, three had meetings with family members who shared child care, such as the father and the grandmother; with the others, the meeting was developed with the familiar main caregiver and the researcher. In total we involved 13 family members.

To ensure anonymity, they were identified alphanumerically (F1 to F10), according to the family nucleus. The invitation was made at the health unit, explaining the purpose of the study. From the obtaining of consent, was organized a meeting with each family in the health unit and at home, nine meetings were held in the hospital environment and only one at home, lasting between thirty minutes and one hour and fifteen minutes.

The demand for child care and the impossibility of relaying between parents and family members were factors that prevented the realization of group meetings with the families of the participating health units. The participation in the domiciliary of only one family was caused by the impossibility of the researcher accompanying other families of children with gastrostomy residing in municipalities outside the metropolitan region of São Luís.

In the meetings with each family, firstly a form was applied to the characterization of the child's primary caregiver. After the family members were oriented in the development of the dynamics of creativity and sensitivity of the CSM called Corpo Saber. A dynamic took place with each participating family. During the dynamics, they expressed their ideas and opinions freely supported by materials such as crayons, wax chalk, watercolor pen, paper sheets with a silhouette of a body that simulated of a child's. At the end of each meeting, a production was obtained that represents the imaginary about the child and the gastrostomy.
The application of the dynamics allowed to understand the family experience with the gastrostomized child and the representations of the chronic condition when indicating in the drawn body the medical-hospital devices, care for the child and feelings that they consider important to him/her. The generative questions used in the dynamics were guided by the experiences of the families during the process of confection of the gastrostomy and transmitted to the participants in language adequate to their understanding.

The information obtained in the dynamics of creativity and sensitivity allows the researcher to uncover the role of subjectivity in the production of knowledge, generate concepts from the body as a unit of thought and action and point out contradictory aspects in the enunciations of the participants. ${ }^{20}$

The operationalization of dynamics requires the development of important moments. In the first moment was organized the environment, reserved and comfortable place in which the participants were welcomed. In the second moment the researcher presented herself, as well as the participants. A quick conversation was held about the child to encourage communication and disinhibition of the family member(s). The third moment corresponds to the explanations about the research, dynamics and its objectives and in the fourth moment, each participant freely exposed their artistic production, the manifestations of each family were verified from the experiences lived during the process of making the gastrostomy. This moment contributed positively to the interview stage; the participants more freely expressed their anguish and fears, enriching the discussions. At the fifth moment, data analysis and validation were performed, with the synthesis of the information provided by the families.

In order to complement the dynamics, the semi-structured interview technique was performed with each family-participant. According to the moment experienced by the family, a script of guiding questions was built up from the process of making the gastrostomy. Additional questions were asked to deepen the understanding on the part of the researcher, reflecting what had been said by the interviewees. The interviews were recorded in audio with prior authorization of the participants and signature of the authorization term for use of image and voice.

At home, all the steps described above were followed, adding another technique to complete the CSM to verify the main demands of child care at home visit, performed by systematic observation, following a script built by the researcher.

The data of the artistic productions, the enunciations of the speeches and the record of the observation in field notes, constituted the primary sources of the investigation. The interviews were transcribed and organized according to the period of the gastrostomy preparation process, namely: the preoperative, the postoperative, the late postoperative at home. The data produced were organized and analyzed through critical and reflexive reading in a thematic-categorial perspective. The 
coding principle was used to extract the generator themes. These themes were decoded into subtopics, and later formed the content of the booklet.

The booklet was constructed following the theoretical references of Freire,$^{19}$ of Pedagogy of Autonomy, based on the guiding axis of the progressive educational practice that seeks to educate for autonomy, promoting the overcoming of naivety for criticality, epistemological curiosity, the appreciation of previous knowledge of people and respect for the learners' knowledge, the need for continuous learning, stimulation of critical, creative and overcoming awareness, acceptance of the new and rejection of any form of discrimination, critical reflection on practice, respect for the autonomy of the other, common sense and apprehension of reality. Based on Peplau's theory, ${ }^{18}$ the dialogue between nurses and the family was taken into account, which favors the negotiation process for care practices. Being close to the family, knowing their cultural context, identifying their fragilities in the care of the gastrostomized child corresponds to the actions of the nurse that distance the illness as the main focus of care and approach their action from the psychological and humanistic model.

\section{RESULTS}

\section{On the profile of family-participants}

The study included 13 family members - mothers, fathers and grandparents - of children aged from 1 month to 7 years who had indication for making gastrostomy for feeding. All the children have the mother as main caregiver, also counting on the participation of the grandmother in two of the participating families.

The profile revealed social and economic limitations in the context in which these families live. It is possible to recognize that many are in a situation of social vulnerability, dependent on the benefits of continued care and the help of family members to ensure survival. One of the families shows concern about maintaining the child's diet and alludes to the high value of the industrialized diets and their financial shortage to guarantee the continuity of enteral nutrition at home. Needing, therefore, to make a request to the competent municipal public agencies.

[...] I have to make a registration so I can get her milk. I have to register because I am poor and cannot afford the milk because it is expensive [...]. (F6-Post-Mediate).

\section{On creative-sensitive and discursive production}

As far as creative-sensitive production is concerned, the families' imagery about the technological devices, their wishes, desires and feelings, as well as the inputs considered important for children, were evidenced. Figure 1 corresponds to the productions of the Body Knowledge dynamics performed with the participants.
Figure 1. Artistic productions of family members in creative and sensitive Body Knowledge dynamics, São Luís - MA, 2017. Source: Study participants.
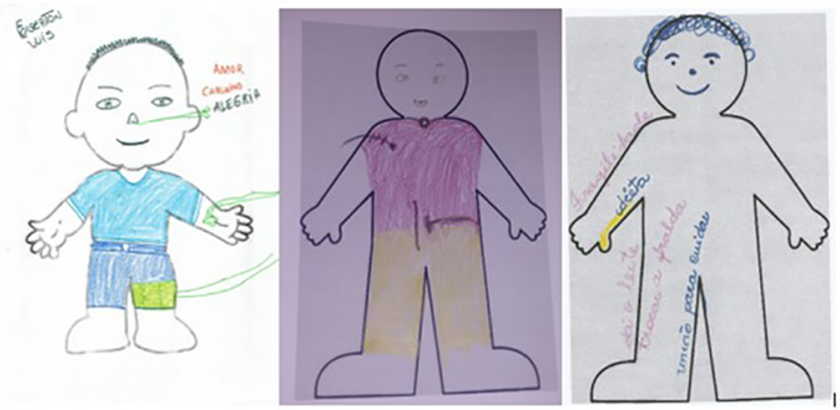

In the productions, the family-participants expressed that the children presented other demands of care besides gastrostomy, such as: tracheostomy, mechanical ventilation, venous access, umbilical catheters and nasogastric.

Regarding the discursive production, it was evidenced that they had information about the care taken, objects of personal use considered important as diapers and diet. Words such as fragility, love, affection and joy were mentioned, as well as the dedication to these children and the need for family unity for continuity of care; also were shown manifestations of sadness and the desire of the return of the physiological way of feeding the child.

There were no differences in the profile or the expressions revealed by the relatives who were in the hospital and home context; some families waiting to be discharged from hospital, and the family at home were more aware of the difficulties that affect the lives of families with children in chronic conditions, such as abandonment of work, high costs with diets and the physical overload that imposes daily care with children. Others pointed out the concern with the distance to go in the search for help of the health professionals, if their children had complications.

As for the data obtained from the participant observation at home, it was verified that the family's primary caregiver understands and implements carefully the care related to the child's nutrition and hydration, as well as general care and with the device; however the home environment presents weaknesses in the physical structure of the environment, such as absence of natural ventilation, artificial lighting and sharing of the child's bed with the mother.

\section{On the problem-situations that emerged from the productions}

Problem-Situation 1:Impasses in the hospitalization process of the children: families reported receiving insufficient information about the situation in which their children were since birth and consequent on the need to transfer to a hospital of greater complexity in the capital. Of the 10 families that participated in the study, eight had as origin cities from the interior of the State. 
She came with an infection. When I got here (referral hospital) it was that I discovered that it was because of meningitis. (F3, Preoperative).

Problem-Situation 2: Lack of knowledge and difficulties regarding gastrostomy: it was verified by the answers that the explanation was insufficient on the diagnosis and the needs of the children, which contributed negatively to the actions of caring of the families in face of the child with gastrostomy.

For now I do not know anything like that, I have no information on how to deal with it. From what I have seen, the surgery is on the belly, that's all I know, it's very close to the navel. I do not think so... because she can sip. Further ahead I doubt if she will be able to swallow. (F3-Preoperative).

Problem-Situation 3: Destruction of the imaginary about the perfect child: it was evidenced that the news of the health problem of a child generates great impact on the family. It is like a dream that falls apart and causes feelings of failure, loss, and unbelief about the situation experienced.

[...] I was a bit surprised when they told me because I did not expect this to happen to my son. Honestly, this is very difficult, my son, it's not being easy. (F4-Preoperative).

Problem-Situation 4: Insufficient health education to meet care demands: it was identified that there are gaps in the educational process in health of the families of children with gastrostomy, in one of the institutions surveyed; information that empowers parents to care for their children is not always provided; relatives seek support from other mothers who also have children with gastrostomies or other sources of information such as the internet.

I don't know how to fight with people like that. Actually I take care of the other mothers, the R.'s mother, I said I'm going to take good care, I'll pay attention when I'm with A., then I know how to handle (the gastrostomy). (F6Post-Mediate).

Problem-Situation 5: Resignation regarding the condition of having a child dependent on technology: it was evident that stomata in children have implied changes in the family routine mainly in the life of the main caregiver. The demands of care are greater and this leads mothers to abandon their work activities in order to dedicate themselves exclusively to the child.

I wake up whenever she aspirating it, because I'm afraid she'll doze ... I'm a pedagogue, but I don't work in the profession, I left everything to take care of her (F10Domicile).

Problem-Situation 6: Loss of physiological normality: it was evidenced that failing to receive food through the mouth represents for the family the loss of physiological normality.

If there only was a day where she would have how to eat again through her mouth I would also want it; only the future will tell. I can't say that... I want it, but I do not know if this "I want" will be answered. (F7-Post-Mediate).

The feelings of loss, sadness and pain in the reports about the impossibility of breastfeeding proved that for the mothers participating in the study, breastfeeding and watching their children savor their food are of great importance.

\section{On the production of care-educational technology}

A mixed approach was adopted for the production of the technology, which allowed considering the needs of the families in the formulation of the contents. Such contents were systematized from the problem-situations that emerged from the creative-sensitive and discursive productions. From there the booklet was made, followed by recommendations for the design and effectiveness of educational materials, according to the following characteristics: content, language, organization, layout, illustration, learning and motivation. ${ }^{21}$

In this way, the booklet aims to promote autonomy and increase the chances of success in home care contributing to the quality of life of these families and their children with gastrostomy. In Table 1, it was presented the relationship between the problem-situations, the subtopics and the nine content topics of the technology.

The technology produced is of the printed type, booklet mode, titled "The child and his gastrostomy: a guide for families and caregivers". Contains 24 pages and nine topics. Among the texts were inserted images to illustrate the respective topics.

\section{DISCUSSION}

When confronted with the socioeconomic reality of the families, it was possible to observe that most of them were immersed in the naive conscience of their new condition, they did not assimilate the harsh reality that presented themselves and they were faced with the sudden need to deal with a deep rearrangement in their lives. It became evident the problem situations that show impersonality, lack of information and inaccuracies expressing feelings of fear and insecurity when dealing with the child's illness, reducing the credibility of the families in relation to the health team.

This problem causes parents to experience a time of great distress and imbalance in their lives and to seek information about 
Table 1. Relation of problem-situations, subthemes and contents of the care-educational technology

\begin{tabular}{|c|c|c|}
\hline Problem-Situations (PS) & Subthemes & Contents of technology \\
\hline $\begin{array}{l}\text { PS1 - Impasses in the hospitalization } \\
\text { process of the child }\end{array}$ & $\begin{array}{l}\text { Reception and basic information for the } \\
\text { families }\end{array}$ & $\begin{array}{l}\text { 1. What is gastrostomy? } \\
\text { 2. What is a gastrostomy for? }\end{array}$ \\
\hline $\begin{array}{l}\text { PS2 - Lack of knowledge and difficulties } \\
\text { regarding gastrostomy }\end{array}$ & $\begin{array}{l}\text { Information about the child's health } \\
\text { problem and gastrostomy }\end{array}$ & $\begin{array}{l}\text { 1. What is gastrostomy? } \\
\text { 2. What is a gastrostomy for? } \\
\text { 3. How long will the child have } \\
\text { gastrostomy? }\end{array}$ \\
\hline $\begin{array}{l}\text { PS3 - Destruction of the imaginary } \\
\text { about the perfect child }\end{array}$ & Information on gastric stomas & $\begin{array}{l}\text { 1. What is gastrostomy? } \\
\text { 2. What is a gastrostomy for? } \\
\text { 3. How long will the child have } \\
\text { gastrostomy? } \\
\text { 4. He/she will stop eating through the } \\
\text { mouth? }\end{array}$ \\
\hline $\begin{array}{l}\text { PS4 - Insufficient health education to } \\
\text { meet the demands of care }\end{array}$ & Health education for child care & $\begin{array}{l}\text { 1. How to prepare the diet for the } \\
\text { gastrostomized child? } \\
\text { 2. How the diet is offered to the child } \\
\text { with gastrostomy? } \\
\text { 3. How to clean the feed tube? } \\
\text { 4. When changing the tube? }\end{array}$ \\
\hline $\begin{array}{l}\text { PS5 - Resignation regarding the } \\
\text { condition of having a child dependent } \\
\text { on technologies }\end{array}$ & The new reality & $\begin{array}{l}\text { 1. What care should I take with } \\
\text { gastrostomy? }\end{array}$ \\
\hline PS6 - Loss of physiological normality & New Feeding Route & $\begin{array}{l}\text { 1. He/she will stop eating through the } \\
\text { mouth? }\end{array}$ \\
\hline
\end{tabular}

Source: Prepared by the author.

their child's situation from other sources because they do not find in the health team the necessary approximation to establish the bond of confidence. ${ }^{11}$

The imaginary of the parents undone before the reality of a child with gastrostomy reveals frustration and dissatisfaction in a difficult and distressing moment. The emotional contribution of other family members, professionals, as a psychologist, nurse among others, as well as religious leaders can help the family to face the new reality, providing a better understanding and coexistence with illness, and not only prioritizing the most important physical care. ${ }^{22}$

The process of health education is paramount to consolidate the families' learning in the care of their children with gastrostomy. It is important that health professionals not only address parental skills in managing their child's illness, but also focus on parental capacity to balance their responsibilities as caregivers of their own personal lives. ${ }^{23}$

This study emphasizes that an improved methodology for standardizing parental education on gastrostomy may be a good option to improve the nurses' ability to prepare families for discharge and reduce their doubts at home. ${ }^{24}$

Due to the need for individualized and specialized care, children need continuous monitoring of health services. At times there is the establishment of a conflictive relationship, or even a total absence of relationship, in which the link with the basic health service is restricted to the simple dispensing of supplies to maintain the technological apparatus. ${ }^{25}$

Care in the perspective of the process of interpersonal nursing relationship is performed through phases in the nurse-patient relationship. These phases overlap, interrelate, and vary in duration as the process evolves into a solution. ${ }^{18}$

The care process for families of gastrostomized children can be developed by the nurse through the use of professional knowledge and their abilities to strengthen the capacity of the caregiver to act on his/her own at home. By using the Peplau Model, it is possible to end dependency on nursing care by recognizing oneself and being cared for as interacting people and co-participants in this process.

The nurse assumes different roles as the relationship develops between the her and the patient, which is in accordance with their desires, with the possibility of helping the other and the adaptation developed throughout the relationship. As an educator, the nurse assists in learning through the patient's experience, allowing her to participate in making decisions for care. ${ }^{26}$

Learning with the other from their own reality, in the actreflect-act process, means that the educator and the learner are involved in learning within a horizontal relationship, with different functions, at the same level of importance. ${ }^{27}$ 
It is necessary to make families aware of the moment they lived. Self-awareness in an act of reflection on oneself, as Freire ${ }^{19}$ points out, is based on awareness, in which the educator-nurse in dialoguing with families will awaken creative and critical attitudes and help them to understand the changes that have occurred during the illness of the child.

This process is reached from the moment they both develop awareness, a state of consciousness in which the human being perceives himself as a man in the world, unfinished and from this conscious act seeks to be for himself to become in a movement of being more. ${ }^{27}$

The process of meaningful learning promotes among students and educators the capacity to become subjects of the construction and reconstruction of the knowledge taught. It is part of the process of liberating education, accepting the risks of the challenge of the new as innovative and enriching..$^{19}$

To help nurses in the health education process, tools built from the experience of care providing information that can direct families to seek new ways to perform home care constitutes an important strategy for the process of investigation of the nursing know-how and that strengthens the education in health.

\section{FINAL CONSIDERATIONS AND IMPLICATIONS FOR PRACTICE}

Children with gastrostomy are part of a share of people with special health needs that are mostly unknown in health services and in statistics. Their families experience knowledges that affect everyone causing the loss of normalcy in family life.

The booklet made can provide families with health information to assist them in the communication process, adherence to treatment and decision-making. So that by becoming conscious, they can seek their rights and thus, get out of passivity and transform their reality before the world.

From the ideas proposed by Peplau, care situations can be used by nurses as learning experiences and personal growth. The nurse has the educational and therapeutic role when encourages people to develop problem solving skills. Thus, the booklet is an educational tool for the nurse with the families of children with gastrostomies. And communicate a technical knowledge to people who have other knowledge and stimulate autonomy and social change. Inspired by Freire's ideas, one must think of education as a permanent character.

For the use of the booklet as educational technology by the nurse with the families of children with gastrostomy, it is recommended their validation. The validation of the content or construct of the educational technology will make it possible to verify if the proposed items present representative content suitable for the intended purpose and are understandable to the target audience. It is a process of investigation of the know-how to do nursing and that strengthens the education in health.

The study identified that a closer relationship between health professionals, children and their families is necessary. Thus, professionals will better understand the difficulties that these families face in their therapeutic itinerary, their socioeconomic conditions and in facing the new reality of having a child with dependence on health care. This way, provoking reflections about the use of innovative strategies guaranteeing a quality home care for these children, as well as for caregiver families.

As limitations of the study, it was pointed out the difficulty of reuniting family members in groups according to the period of the gastrostomy preparation process and the reduced number of families surveyed at home. Also, insufficient time to perform validation of the booklet; hence the importance of following up this work and other studies that contemplate methodological innovations in search of an effective care and sensitive to the needs of the family, children and adolescents dependent on technologies.

\section{REFERENCES}

1. Moreira MCN, Gomes R, Sá MRC. Doenças crônicas em crianças e adolescentes: uma revisão bibliográfica. Ciênc Saúde Coletiva [Internet]. 2014; [cited 2017 Apr 10]; 19(7):2083-94. Available from: http://www. scielo.br/scielo. php? pid=S1413-81232014000702083\&script=sci_ abstract\&tlng=pt

2. Pinto MB, Soares CCD, Santos NCCB, Pimenta EAG, Reichert APS, Collet N. Perception of mothers about the school inclusion of children with chronic disease. Rev Enferm UFPE On Line [Internet]. 2017; [cited 2017 May 10]; 11(3):1200-6. Available from: http://www.revista.ufpe.br/ revistaenfermagem/index.php/revista/article/viewArticle/9879

3. Organização Mundial da Saúde - OMS. Cuidados inovadores para condicões crônicas: componentes estruturais de ação: relatório mundial. Brasília (DF): Organização Mundial da Saúde; 2003.

4. Goltrand F, Sulivan PB. Gastrostomy tube feeding: when to start, what to feed and how to stop. Eur J Clin Nutr [Internet]. 2010 May; [cited 2017 May 15]; 64 Suppl 1:S17-21. Available from: https://www.ncbi.nlm.nih. gov/pubmed/20442720

5. Pereira F.A gastrostomia endoscópica na nutrição entérica da criança. $J$ Port Gastrenterol [Internet]. 2011 Nov; [cited 2017 Apr 15]; 18(6):268-9. Available from: http://www.scielo.mec.pt/scielo.php?script=sci_arttext\& pid=S0872-81782011000600001

6. Baker L, Beres AL, Baird R. A systematic review and meta-analysis of gastrostomy insertion techniques in children. J Pediatr Surg [Internet] 2015 May; [cited 2016 Mar 3]; 50(5):718-25. Available from: https://www. ncbi.nlm.nih.gov/pubmed/25783383

7. Crowley JJ, Hogan MJ, Towbin RB, Saad WE, Baskin KM, Marie Cahil A, et al.; Society of Interventional Radiology Standards of Practice Committee; Society for Pediatric Radiology Interventional Radiology Committee. Quality improvement guidelines for pediatric gastrostomy and gastrojejunostomy tube placement. J Vasc Interv Radiol [Internet] 2014 Dec; [cited 2015 Oct 22]; 25(12):1983-91. Available from: https:// www.ncbi.nlm.nih.gov/pubmed/25439676

8. Sumritsopak R, Treepongkaruna S, Butsriphum N, Tanpowpong P. Percutaneous Endoscopic Gastrostomy in Children: Caregivers Perspectives. J Pediatr Nurs [Internet]. 2015 Jul/Aug; [cited 2017 Apr 15]; 30(4):e3-7. Available from: https://www.ncbi.nlm.nih.gov/ pubmed/25448473

9. Guerreiro S, Angelo M. Impacto del estoma enteral em el niño y la família Av Enferm [Internet]. 2010; [cited 2017 Apr 18]; 28(no.espe):99-108 Available from: https://revistas.unal.edu.co/index.php/avenferm/article/ view/21453

10. Mahant S, Jovcevska V, Cohen E. Decision-making around gastrostomyfeeding in children with neurologic disabilities. Pediatrics [Internet]. 2011 Jun; [cited 2017 Mar 18]; 127(6):e1471-81. Available from: https://www. ncbi.nlm.nih.gov/pubmed/21624876 
11. Vilar AMA, Andrade M, Alves MRS. Alta de crianças com estoma: uma revisão integrativa da literatura. Rev Enferm Refer [Internet]. $2013 \mathrm{Jul}$ [cited 2017 Mar 18]; 10:145-52. Available from: Available from: http:// www.scielo.mec.pt/pdf/ref/vserllln10/serllln10a17.pdf

12. Okido ACC, Zago MMF, Lima RAG. O cuidado do filho dependente de tecnologia e suas relações com os sistemas de cuidados em saúde. Rev Latino Am Enferm [Internet]. 2015 Mar/Apr; [cited 2017 May 25]; 23(2):291-8. Available from: http://www.scielo.br/pdf/rlae/v23n2/ pt_0104-1169-rlae-23-02-00291.pdf

13. Salbego C, Nietsche EA, Teixeira E, Böck A, Cassenote LG. Tecnologias cuidativo-educacionais: um conceito em desenvolvimento. In: Teixeira $\mathrm{E}$, org. Desenvolvimento de tecnologias cuidativo-educacionais. Porto Alegre: Moriá; 2017. p. 31-50.

14. Aredes NDA, Dias DMV, Fonseca LMM, Campbell SH, Martins JCA, Rodrigues MA. E-baby integridade da pele: inovação tecnológica no ensino de enfermagem neonatal baseado em evidências. Esc Anna Nery [Internet]. 2018; [cited 2018 Sep 14]; 22(3):e20170424. Available from: http://www.scielo.br/pdf/ean/v22n3/pt_1414-8145-ean-2203-e20170424.pdf

15. Cordeiro LI, Lopes TO, Lira LEA, Feitoza SMS, Bessa MEP, Pereira MLD, et al. Validation of educational booklet for HIV/Aids prevention in older adults. Rev Bras Enferm [Internet]. 2017; [cited 2018 Sep 14]; 70(4):775-82. Available from: http://www.scielo.br/pdf/reben/v70n4/ pt_0034-7167-reben-70-04-0775.pdf

16. Dalmolin A, Girardon-Perlini NMO, Coppetti LC, Rossato GC, Gomes JS, Silva MEN. Vídeo educativo como recurso para educação em saúde a pessoas com colostomia e familiares. Rev Gaúcha Enferm [Internet]. 2016; [cited 2018 Sep 14]; 37(no.espe):e68373. Available from: http://www.scielo.br/pdf/rgenf/v37nspe/0102-6933-rgenf-198314472016esp68373.pdf

17. Ilha S, Santos SSC, Backes DS, Barros EJL, Pelzer MT, Oliveira AMN. (Geronto) Tecnologia cuidativo-educacional na doença de Alzheimer e no apoio ao idoso/família: perspectiva dos docentes e discentes. Esc Anna Nery [Internet]. 2017; [cited 2018 Sep 14]; 21(2):e20170039. Available from: http://www.scielo.br/pdf/ean/v21n2/1414-8145-ean21-02-e20170039.pdf
18. Peplau HE. Interpersonal relations in nursing: a conceptual frame of reference for psycodynamic nursing. Basingstoke: Palgrave Macmillan; 2002.

19. Freire P. Pedagogia da autonomia: saberes necessários à prática educativa. 49a ed. Rio de Janeiro: Paz e Terra; 2014.

20. Cabral IE. O método criativo e sensível: alternativa de pesquisa em enfermagem. In: Gauthier JHM, Cabral IE, Santos I, Tavares CMM, orgs. Pesquisa em enfermagem: novas metodologias aplicadas. Rio de Janeiro: Guanabara Koogan; 1998. p. 177-208.

21. Jewish General Hospital - JGH. How to Create Effective Written Patient Learning Materials. [Internet]. 2008 [cited 2017 Mar 18]. Available from: http://www.jgh.ca/uploads/Library/HandbookEngJan20.pdf

22. Souza LCSL, Nitschke RG, Souza AIJ. O cuidado de Enfermagem no hospital na percepção das famílias: desafios e perspectivas para a profissão. In: Elsen I, Souza AIJ, Marcon SS, orgs. Enfermagem à família: dimensões e perspectivas. Maringá: Eduem; 2011. p. 97-114.

23. Geense WW, van Gaal BGI, Knoll JL, Cornelissen EAM, van Achterberg $\mathrm{T}$. The support needs of parentes having a child with a chronic kidney disease: a focus group study. Child Care Health Dev [Internet]. 2017 Nov; [cited 2018 Jan 21]; 43(6):831-8. Available from: https://www.ncbi. nlm.nih.gov/pubmed/28547746

24. Kirk L, Shelley A, Battles M, Latty C. Educating parentes on gastrostomy devices: necessary components to achieve success. J Pediatr Nurs [Internet]. 2014 Sep/Oct; [cited 2017 Apr 20]; 29(5):457-65. Available from: https://www.ncbi.nlm.nih.gov/pubmed/24905434

25. Lima MF, Paulo LF, Higarashi IH. Crianças dependentes de tecnologia: o significado do cuidado domiciliar. Online Braz J Nurs [Internet]. 2015 [cited 2017 Apr 10]; 14(2):1066-73. Available from: http://www.scielo. $\mathrm{br} / \mathrm{pdf} / \mathrm{reeusp} / \mathrm{v} 46 \mathrm{n} 5 / 05 . \mathrm{pdf}$

26. Peplau HE. Relaciones interpersonales en enfermería: Un marco de referencia conceptual para la enfermeira psicodinâmica. Barcelona: Ediciones Científicas y Técnicas; 1993.

27. Funai A, Silva Filho C, Maestri E, Martini JG. Saberes necessários à prática educativa: ensinar é uma especificidade humana. In: Prado ML, Reibnitz KS. Paulo Freire: a boniteza de ensinar e aprender na saúde. Florianópolis: NFR/UFSC; 2016. [Internet]. [cited 2016 Oct 14] p. 99-116. Available from: ebooks-saude.sites.ufsc.br

\footnotetext{
a Article extracted from the master's thesis "Tecnologia cuidativo-educacional para promoção da autonomia de famílias de crianças com gastrostomia", defended by Ana Caroline Silva Caldas under the guidance of Santana de Maria Alves de Sousa, in the Graduate Program in Nursing. Year 2017.
} 